\title{
Physicochemical properties and fatty acid profile of Allanblackia seed oil and African pear pulp oils
}

\author{
Akusu, O. M. ${ }^{*} \bullet$ Wordu, G. 0 . \\ Department of Food Science and Technology, Rivers State University, Nkpolu Oroworukwo, P. M. B., 5080, Port Harcourt, Nigeria. \\ *Corresponding author. E-mail: akusu.monday@yahoo.com
}

Accepted $5^{\text {th }}$ March, 2019.

\begin{abstract}
Edible oils were extracted from the pulp of African pear (Dacryodes edulis) and the seed of tallow tree (Allanblackia floribunda), given a yield of 48.93 and $65.31 \%$, respectively. The oil samples were analyzed for chemical composition, physical properties, and fatty acid profile. Total saturated fatty acids of 51.64 and $34.12 \%$ were obtained from Allanblackia seed oil and African pear pulp oil, respectively, while $48.36 \%$ and $65.88 \%$ were recorded values for Total unsaturated fatty acids from Allanblackia seed oil and African pear pulp oil, respectively. African pear pulp oil gave $23.17 \%$ linoleic acid as against $1.18 \%$ in Allanblackia seed oil. The iodine value of African pear pulp oil (APPO) was $58.05 \mathrm{~g} / 100 \mathrm{~g}$, this figure was significantly higher than that of Allanblackia seed oil (ASO) (40.29 g/100 g), and not significantly different $(P>0.05)$ from the iodine value of the control (crude palm oil). Percentage free fatty acid (FFA) of 0.556 and 0.146 for APPO and ASO, respectively, were significantly $(P<0.05)$ lower than that of the control CPO with FFA of $3.33 \%$. The peroxide value (PV) of APPO and ASO were respectively 0.90 and $0.49 \mathrm{mEq} / \mathrm{kg}$, which were significantly lower $(P<0.05)$ than $1.53 \mathrm{mEq} / \mathrm{kg}$ shown in the control $(C P O)$. The slip melting point of African pear pulp oil, Allanblackia seed oil and crude palm oil were, respectively, $25.34,35.40$ and $32.57^{\circ} \mathrm{C}$. Values for Lovibond colour intensity were 2.5, 6.0 and 11 red for Allanblackia seed oil, African pear pulp oil and crude palm oil, respectively. Allanblackia seed oil, with a melting point of $35.40^{\circ} \mathrm{C}$ will provide a good solid base for bakery fat production, while Africa pear pulp oil rich in polyunsaturated fatty acids will provide healthy and essential fatty acids.
\end{abstract}

Keywords: Tallow tree, African pear, physicochemical, fatty acid profile.

\section{INTRODUCTION}

Allanblackia seeds and African pear pulp are good sources of fats and oil. Allanblackia seed oil is obtained from the seeds of vegetable tallow tree (Allanblackia floribunda), which exist in the wild in most parts of Africa. The tallow tree ( $A$. floribunda) is a woody dicotyledonous and underutilized plant belonging to the family Guttiferae and the genus Allanblackia. It is an evergreen plant that thrives well in wet places especially in the rainforest regions, producing big brown fruits. Inside those fruits are the seeds that contain the Allanblackia oil (Atangana et al., 2011). The trees are widely distributed in certain parts of Africa, mostly in Sierra Leone to Cameroon and Gabon, Congo Brazzaville and Uganda. Traditionally, the oil extracted from its seeds has been used locally for cooking, preparing medicines and making soap at a subsistence level. It has recently been found that the oil could be used in the manufacturing of spreads (margarine), soap and beauty products. Several properties of this oil, for example high melting point and better food value among others, make it superior to alternatives like palm oil (Novella Partnership, 2008).

African pear (Dacryodes edulis) tree belongs to the Burseraceae family and is found in Africa where it is distributed from Ghana to Angola through Congo Brazzaville. In Cameroon, it is mostly found in the south and in the Adamawa plateau (Noumi et al., 2014). The fruit pulp is generally eaten fresh or roasted. It is an important source of oil with a content of $50 \%$ dry weight 


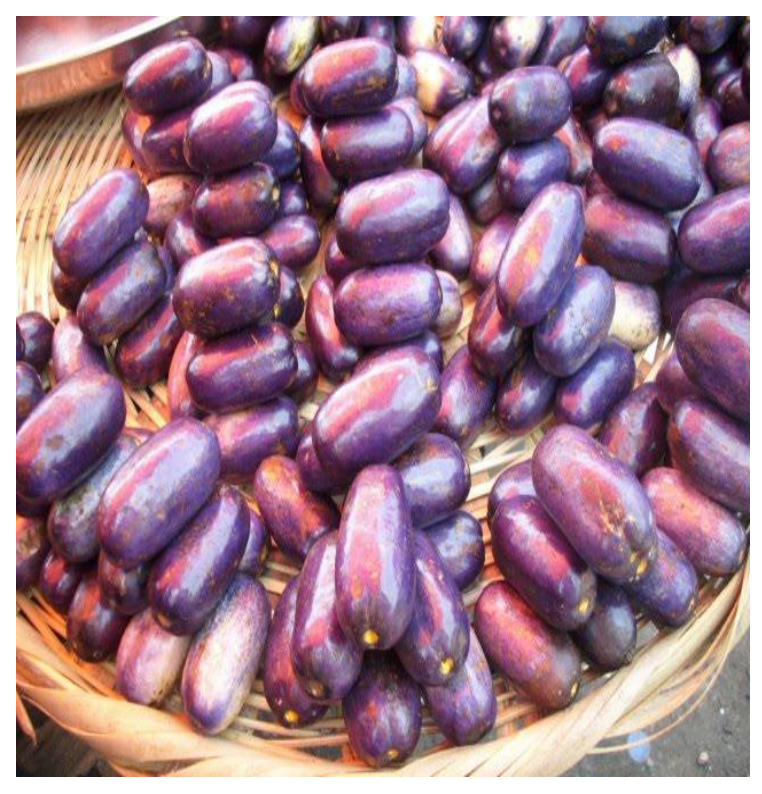

Figure 1. African pear fruits.

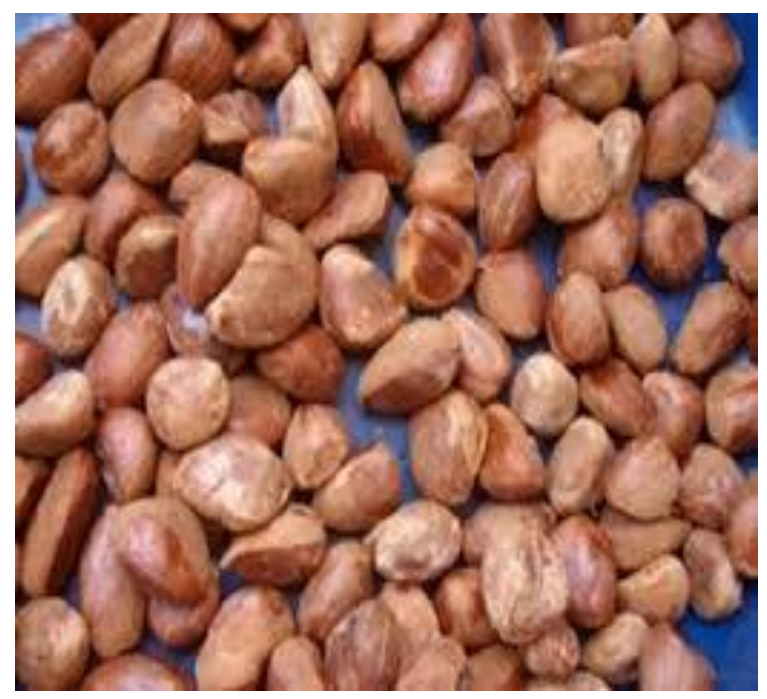

Figure 2. Allanblackia seed.

(Silou, 2012; Kapseu et al., 1999). Fruits are fragile and about one half of harvested fruits are lost due to softening and spoiling (Noumi et al., 2014). Allanblackia seed and African pear pulp oils have great potential as major raw material in the food process Industry, in manufacturing, baking, frying and other culinary uses. Yet they are underutilized in Nigeria. The blend of Allanblackia seed oil (a solid fat) and African pear pulp oil, rich in essential polyunsaturated fatty acids could be used to produce bakery shortening and margarine with improved functionalities, nutrition and health value. Shortenings are tailored fat systems, whose nutritional and functional properties have been modified in order to deliver specific functional needs; as tenderizing agents, facilitate aeration, texture, mouthfeel, carry flavours and colours, provide a heating medium, and structural integrity to pies, breads, pasta and other bakery products (Rios et al., 2014; Chibor et al., 2017). Allanblackia seed and African pear pulp oils are highly underutilized in Nigeria, in spite of their huge potential. These oils could serve as a better alternative to hydrogenated palm stearin, which is predominantly used in Nigeria for margarine and shortening production. Use of Allanblackia seed and African pear pulp oils in bakery shortening formulation will further enhance the utilization of these agricultural raw materials. The objective of this study was to evaluate the physicochemical properties and fatty acid profile of Allanblackia seed and African pear pulp oils, such that their utilization in domestic and industrial purposes could be further enhanced.

\section{MATERIALS AND METHODS}

\section{Sources of research materials and procedure for oil extraction}

Mature and good quality fruits from the African pear (Dacryodes edulis) (Figure 1) were purchased from the fruit market in Port Harcourt, Nigeria. The fruits were of optimum ripening as indicated in the complete bluishblack colour of the epicarp. Matured fruits of Allanblackia floribunda (Figure 2) were obtained from Okehi and Igbodo in Eche Local government area of Rivers State, Nigeria. The Allanblackia seeds were cracked and sorted. The mesocarp of matured African pear fruits were extracted and washed. The Allanblackia seeds and African pear mesocarp were both oven dried at $60^{\circ} \mathrm{C}$, for $24 \mathrm{~h}$, separately in a hot air oven (model QUB 305010G, Gallenkamp, UK), ground using a laboratory mill (model MXAC2105, Panasonic, Japan), this was followed by oil extraction as described by AOAC (2012). Oil was also extracted from the mesocarp of freshly harvested palm fruits and used as control.

\section{Determination of physicochemical properties}

Physicochemical properties including; acid value, iodine value, free fatty acids, peroxide value, Saponification value, Unsaponifiable matter, melting point, Refractive index and density were determined by the method of AOAC (2012). Viscosity measurement (in centistokes, cSt) was performed using an Ubbelohde glass capillary viscometer (size 2. A149, Cannon instrument, PA, USA). Refractive index was performed using the Abbe Refractometer model 2WAJ (Wincom, China).

\section{Determination of fatty acid profile}

The individual fatty acids in the oil/fats were determine 
using the A. O. A. C (2012) methods. Fatty acid methyl esters (FAME) were prepared from the extracted fats/oil. In $50 \mathrm{ml}$ round bottom flasks, $50 \mathrm{mg}$ of each sample was kept in separate flasks and $3 \mathrm{ml}$ of sodium methylate solution $(0.5 \mathrm{~mol} / \mathrm{L}$ of methanolic solution of $\mathrm{NaOH})$ was added. The reaction medium was refluxed for $10 \mathrm{~min}$; 3 $\mathrm{ml}$ of acetyl chloride was added; mixture was refluxed again for $10 \mathrm{~min}$ and then cooled to ambient temperature; $8 \mathrm{ml}$ hexane and $10 \mathrm{ml}$ of distilled water was added and allowed to stand for $5 \mathrm{~min}$ to establish a two phase solution. The upper organic phase was recovered into a vial for GC analysis, using Agilent 7890A, coupled with flame-ionization detector (FID).

\section{GC conditions}

Gas Chromatography: Agilent 7890A, coupled with flameionization detector (FID)

Column: Agilent19091J-413:2777.61484, Hp-5 5\% phenyl methyl siloxane

$325^{\circ} \mathrm{C}: 30 \mathrm{~m} \times 320 \times \mu \mathrm{m} \times 0.25 \mu \mathrm{m}$.

Syringe size: $10 \mu \mathrm{l}$; injection volume: $1 \mu \mathrm{l}$; carrier gas: He (helium); injection temperature: $250^{\circ} \mathrm{C}$; pressure: 7.8696 psi.

Detector temperature: $290^{\circ} \mathrm{C}$;

Oven programme. A: $6^{\circ} \mathrm{C}$ for $2 \mathrm{~min}$, then $10^{\circ} \mathrm{C} / \mathrm{min}$ to $200^{\circ} \mathrm{C}$ for $0 \mathrm{~min}$

B: then $5^{\circ} \mathrm{C} / \mathrm{min}$ to $240^{\circ} \mathrm{C}$ for $7 \mathrm{~min}$. run time: $31 \mathrm{~min}$

\section{Identification and quantification}

Identification of individual fatty acids was based on a comparison of the retention times and chromatographic profiles measured in the sample, with the retention times and profiles shown in the chromatograms of the (external) standard oils. The content of individual fatty acids was expressed as a percentage of the total content of all acids in the sample.

\section{Determination of solid fat content}

The solid fat content-temperature profile was determined using the density method, as noted by Nazaruddin (2013). Density of solid fat is higher than the density of liquid oil, so density increase when fat crystalizes and decrease when it melts.

The glass pycnometer was used to measure density at the following temperature: $5,10,15,20,25,30,35,40$, 45 and $50^{\circ} \mathrm{C}$. The percentage SFC was calculated following the McClements (1999) equation as earlier used by Kiin-Kabari et al. (2018).

SFC $(\%)=\frac{\rho-\rho l}{\rho s-\rho l} \times \frac{100}{1}$

$D=$ density of fat at the desired temperature
$\mathrm{DI}=$ density of fat when completely liquid.

Ds $=$ density of fat when completely solid.

\section{Statistical analysis}

All the analyses were carried out in duplicate. Data obtained were subjected to Analysis of variance (ANOVA), differences between means were evaluated using Tukey's multiple comparison test, and significance accepted at $P \leq 0.05$ level. The statistical package in Minitab 16 computer program was used.

\section{RESULTS AND DISCUSSION}

\section{Percentage fat content}

From Figure 3, Allanblackia seed contained $65.31 \%$ fat, while African pear pulp gave $48.93 \%$ fat. The percentage fat in the palm fruit mesocarp was $50.00 \%$. Fat content of 61.2 and $67.59 \%$ for Allanblackia seed were earlier reported (Folarin et al., 2017; Wilfred et al., 2010), fat content of $44.6 \%$ had also been reported for African pear pulp (Ogoloma et al., 2013). This indicates that Allanblackia seed and African pear pulp are rich sources of vegetable oil.

\section{Chemical properties of Allanblackia seed oil, African pear pulp oil and crude palm oil}

Result for the chemical properties of Allanblackia seed oil, African pear pulp oil and crude palm oil is presented in Table 1. The iodine value of African pear pulp oil was significantly higher than those of Allanblackia seed oil and the control (crude palm oil). Minimum standard for iodine value in crude palm oil is $50.4 \mathrm{~g} / 100 \mathrm{~g}$ (MS 814, 2007; IS 8323, 2014). Iodine value of $58.05 \mathrm{~g} / 100 \mathrm{~g}$ indicates that African pear pulp oil contains more heartfriendly unsaturated fatty acids than Allanblackia seed oil. lodine value is a simple chemical constant used to measure the degree of unsaturation or the average number of double bonds in an oil sample. It is the number of grams of iodine that could be used to halogenate $100 \mathrm{~g}$ of oil (Ononogbu, 2002; Shahidi, 2005).

Percentage free fatty acid (FFA) of African pear pulp oil and Allanblackia seed oil were significantly $(P<0.05)$ lower than that of the control CPO. The suitability of African pear pulp oil and Allanblackia seed oil for margarine and bakery shortening production, and other food product formulations is greatly enhanced by the low FFA value. With low free fatty acid, the cost and energy required for refining and modifications will be drastically reduced. African pear pulp oil sample need some level of refining to further reduce the FFA to $\leq 0.25 \%$, which is the standard value of FFA for refined vegetable oil (IS:8323, 2014). While Allanblackia seed oil need no further 


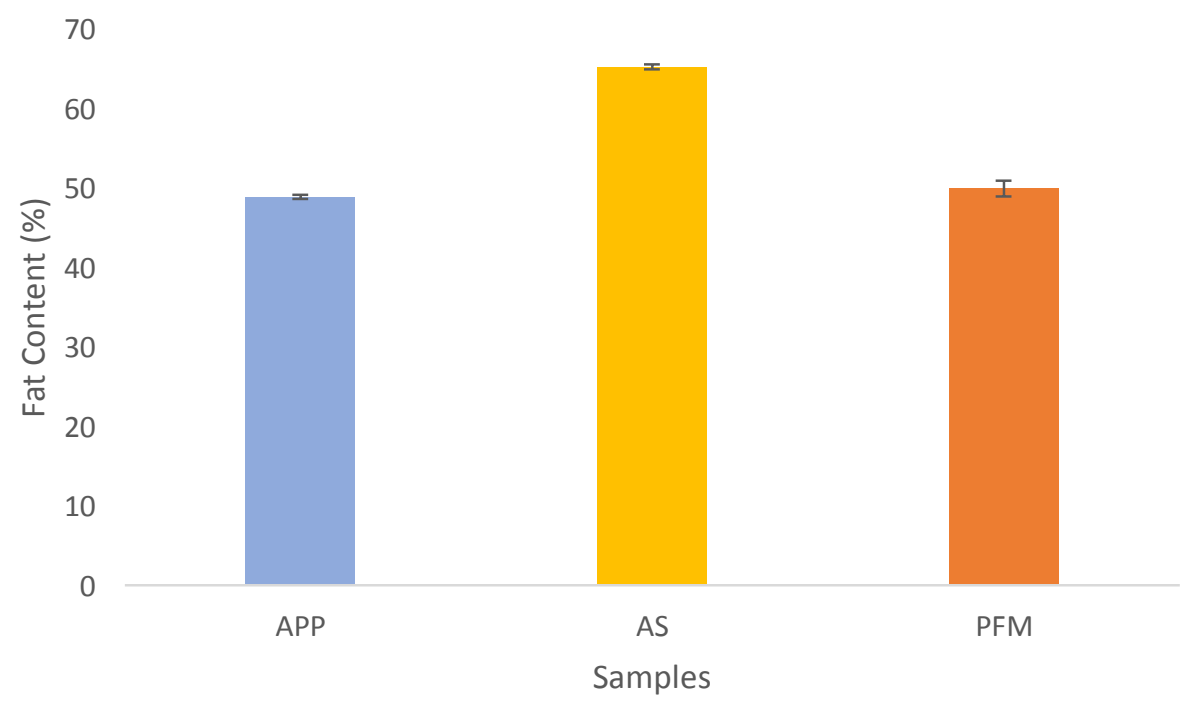

Figure 3. Percentage fat content of Allanblackia seed, African pear pulp and palm fruit mesocarp. Key: APP = African pear pulp; $A S=$ Allanblackia Seed; PFM = palm fruit mesocarp.

Table 1. Chemical properties of African pear pulp oil, Allanblackia seed oil and palm oil.

\begin{tabular}{lcccccc}
\hline Sample & $\begin{array}{c}\text { IV } \\
(\mathbf{g} / \mathbf{1 0 0} \mathbf{g})\end{array}$ & $\begin{array}{c}\text { FFA } \\
(\%)\end{array}$ & $\begin{array}{c}\text { PV } \\
(\mathbf{m E q} / \mathbf{k g})\end{array}$ & $\begin{array}{c}\text { SV } \\
\text { MgKOH/g }\end{array}$ & $\begin{array}{c}\text { USM } \\
(\%)\end{array}$ & $\begin{array}{c}\text { Moisture } \\
(\%)\end{array}$ \\
\hline APPO & $58.05 \pm 0.290^{\mathrm{a}}$ & $0.558 \pm 0.001^{\mathrm{b}}$ & $0.90 \pm 0.006^{\mathrm{b}}$ & $186.05 \pm 0.085^{\mathrm{b}}$ & $0.21 \pm 0.009^{\mathrm{c}}$ & $0.11 \pm 0.014^{\mathrm{b}}$ \\
ASO & $40.29 \pm 0.389^{\mathrm{b}}$ & $0.146 \pm 0.006^{\mathrm{c}}$ & $0.49 \pm 0.00^{\mathrm{b}}$ & $199.62 \pm 0.113^{\mathrm{a}}$ & $0.63 \pm 0.013^{\mathrm{a}}$ & $0.13 \pm 0.007^{\mathrm{b}}$ \\
CPO & $57.33 \pm 0.17^{\mathrm{a}}$ & $3.33 \pm 0.042^{\mathrm{a}}$ & $1.53 \pm 0.170^{\mathrm{a}}$ & $200.47 \pm 0.119^{\mathrm{a}}$ & $0.55 \pm 0.028^{\mathrm{b}}$ & $0.47 \pm 0.00^{\mathrm{a}}$ \\
\hline
\end{tabular}

Values are means \pm standard deviation of duplicate samples.

Mean values bearing different superscripts in the same column differ significantly $(p<0.05)$.

Key: FFA = free fatty acid, PV = Peroxide value, IV = lodine Value, SV = Saponification value, USM = Unsaponifiable matter, APPO = African pear pulp oil, $\mathrm{ASO}=$ Allanblackia seed oil, $\mathrm{CPO}=$ Crude palm oil .

refining.

The peroxide value (PV) of African pear pulp oil and Allanblackia seed oil were significantly lower $(P<0.05)$ than that of the control (CPO). The PV of all the oil samples were lower than $10 \mathrm{mEq} / \mathrm{kg}$, which is the maximum allowable value for PV (CODEX, 1999). Peroxide value (PV) gives an indication of the degree of fat oxidized (Ononogbu, 2002; Okashi et al., 2013). It is the milliequivalent $(\mathrm{mEq})$ of oxygen per $\mathrm{kg}$ of fat. Oxidation of an unsaturated oil takes place through the formation of hydroperoxides. The hydroperoxides being the primary products of oxidation do not have any offflavour (Gordon, 1993).

African pear pulp oil gave SV of $186.05 \mathrm{mgKOH} / \mathrm{g}$ which was higher than $179.52 \mathrm{mgKOH} / \mathrm{g}$ reported earlier by Ajayi and Adesanwo (2009). Saponification value of the sample oils were high. High saponification value is an indicator for fat/oil suitability for industrial use. High saponification value is suitable for soaps and shampoo, pharmaceutical, and food processing (Aremu et al., 2015), low saponification value is also suitable for food processing. Saponification value is a measure of the alkali-groups in fats and oil and is defined as the $\mathrm{mg} \mathrm{KOH}$ needed to saponify $1 \mathrm{~g}$ of oil (Shahidi, 2005). It is a measure of all the saponifiable fatty acids (including the esters) present in oil (Aremu et al., 2015). It is the amount of potassium hydroxide (in $\mathrm{mg}$ ) required to neutralize the fatty acids that results from complex hydrolysis of $1 \mathrm{~g}$ of oil.

The percentage unsaponifiable matter content of Allanblackia seed oil was significantly $(P<0.05)$ higher than African pear pulp oil and the control (CPO). Nahm (2011) reported that the considerably high presence of USM is an indication that the oil is rich in desirable bioactive components such as; antimicrobial, antioxidants, and anti-inflammatory substances, including the fat soluble vitamins. These components had been used by a pharmaceutical company, BSP Pharma, to lower cholesterol levels (Masters et al., 2004).

The moisture and volatile matter content of African pear pulp oil and Allanblackia seed oil were significantly $(\mathrm{P}<0.05)$ lower than that of CPO, and lower than $0.20 \%$, which is the maximum allowable moisture content for refined vegetable oil (CODEX, 2011). Low moisture 
Table 2. Fatty acid profile of Allanblackia seed oil (ASO), African pear pulp oil (APPO) and crude palm oil (CPO).

\begin{tabular}{lccc}
\hline \multirow{2}{*}{ Fatty acids (\%) } & \multicolumn{3}{c}{ Fat samples } \\
\cline { 2 - 4 } & ASO & APPO & CPO \\
\hline Lauric (C12:0) & 0.15 & & \\
Myristic (C14:0) & 0.1 & 2.00 & 1.00 \\
Palmitic (C16:0) & 1.39 & 15.18 & 46.50 \\
Palmitoleic (C16:1) & 0.10 & 1.20 & 0.20 \\
Stearic (C18:0) & 49.87 & 14.84 & 2.60 \\
Oleic (C18:1) & 44.87 & 40.45 & 39.70 \\
Linoleic (C18:2) & 1.18 & 23.17 & 9.20 \\
Arachidic (C20:0) & 0.13 & 2.10 & 0.30 \\
Eicosenoic (C20:1) & 0.97 & 0.91 & 0.20 \\
Eicosadienoic (C20:2) & 1.24 & 0.84 & \\
Eicosatrienoic (C20:3) & & 0.51 & \\
\hline
\end{tabular}

Key: APPO = African pear pulp oil, ASO = Allanblackia seed oil, $\mathrm{CPO}=$ crude palm oil.

content of oil enhances oxidative stability.

\section{Fatty acid profile of Allanblackia seed oil (ASO), African pear pulp oil (APPO) and crude palm oil (CPO)}

From Table 2, Allanblackia seed oil (ASO) contains $51.64 \%$ total saturated and $48.36 \%$ total unsaturated fatty acids. Stearic acid was the predominant saturated fatty acid, while oleic acid was the predominant unsaturated fatty acid recorded in ASO.

African pear pulp oil (APPO) contained 34.12\% saturated and $68.88 \%$ unsaturated fatty acids respectively. Oliec acid being the predominant unsaturated fatty acid was $40.45 \%$, it also contained $23.17 \%$ linoleic acid (omega-6) and $0.51 \%$ ecosatrienoic acid (omega-3), higher than linoleic acid contained in palm oil. High content of polyunsaturated fatty acid in African pear pulp oil and its linoleic acid content makes it a rich source of essential fatty acid, with great potentials to enhance the nutritional value of its food products. (Figure 4 to 6)

\section{Physical properties of Allanblackia seed oil, African pear pulp oil and crude palm oil}

From Table 3, the RI of African pear pulp oil was 1.4675, this value was greater than $\mathrm{RI}$ of 1.462 reported by Ikhuoria and Maliki (2007) for Dacryodes edulis pulp oil and 1.231 reported for avocado pear oil (Orheuba and Jinadu, 2011). Allanblackia seed oil gave RI of 1.465, this value was relatively higher than 1.460 earlier given by Wilfred et al., (2010). Refractive index of fat had been reported to increase with increase in chain length of the fat, and also with the number of unsaturated bonds present in the fat (Nielson, 1994). Refractive index of palm oil was 1.456, this value was within the range (1.452 to 1.456) recommended for crude palm oil by the Indian Standard (IS 8323, 2014) and Malaysian Standard (MS 814, 2007). Refractive Index also depends on the degree of conjugation as well as the degree of unsaturation of the oil (Shahidi, 2005). Higher value of RI recorded by African pear pulp oil is an indication that the oil contains more unsaturated fatty acids than Allanblackia seed oil, and palm oil. The refractive index is the ratio of the speed of light in a vacuum to the speed of light in the fat sample, it is related to the degree of saturation of the oil (Nelson 1994). RI had been shown to provide hint on oxidative damage (Hoffman, 1986).

African pear pulp oil had viscosity value that compares favourably with that of the control (CPO). The kinematic viscosity of Allanblackia seed oil at $40^{\circ} \mathrm{C}$ was $21.76 \mathrm{cSt}$, which was significantly $(P<0.05)$ lower than African pear pulp oil (APPO) and the control crude palm oil (CPO). Allanblackia seed oil though solid at room temperature $\left(28 \pm 2^{\circ} \mathrm{C}\right)$ flows with less resistance at $40^{\circ} \mathrm{C}$, as shown by the viscosity value of $21.76 \mathrm{cSt}$. Viscosity defines the resistance to flow for fats/oils. It decreases with increasing unsaturation and high temperature (Nourrechni et al., 1992).

From Table 3, the density of African pear pulp oil and Allanblackia seed oil were not significantly different $(P>$ 0.05 ), but significantly lower than $0.900 \mathrm{~g} / \mathrm{ml}$ given by the control (crude palm oil), and 0.900 to 0.912 which is the standard density for crude palm oil (IS 8323, 2014). The higher the density of a fat, the higher the presence of solid fats (Nazaruddin, 2013), which enhances plasticity in the fat products. The density provides information on the solid content of the fat as well as its weight at a particular temperature (Aremu et al., 2015). It is the ratio of the weight of the oil to its volume.

African pear pulp oil and Allanblackia seed oil gave 


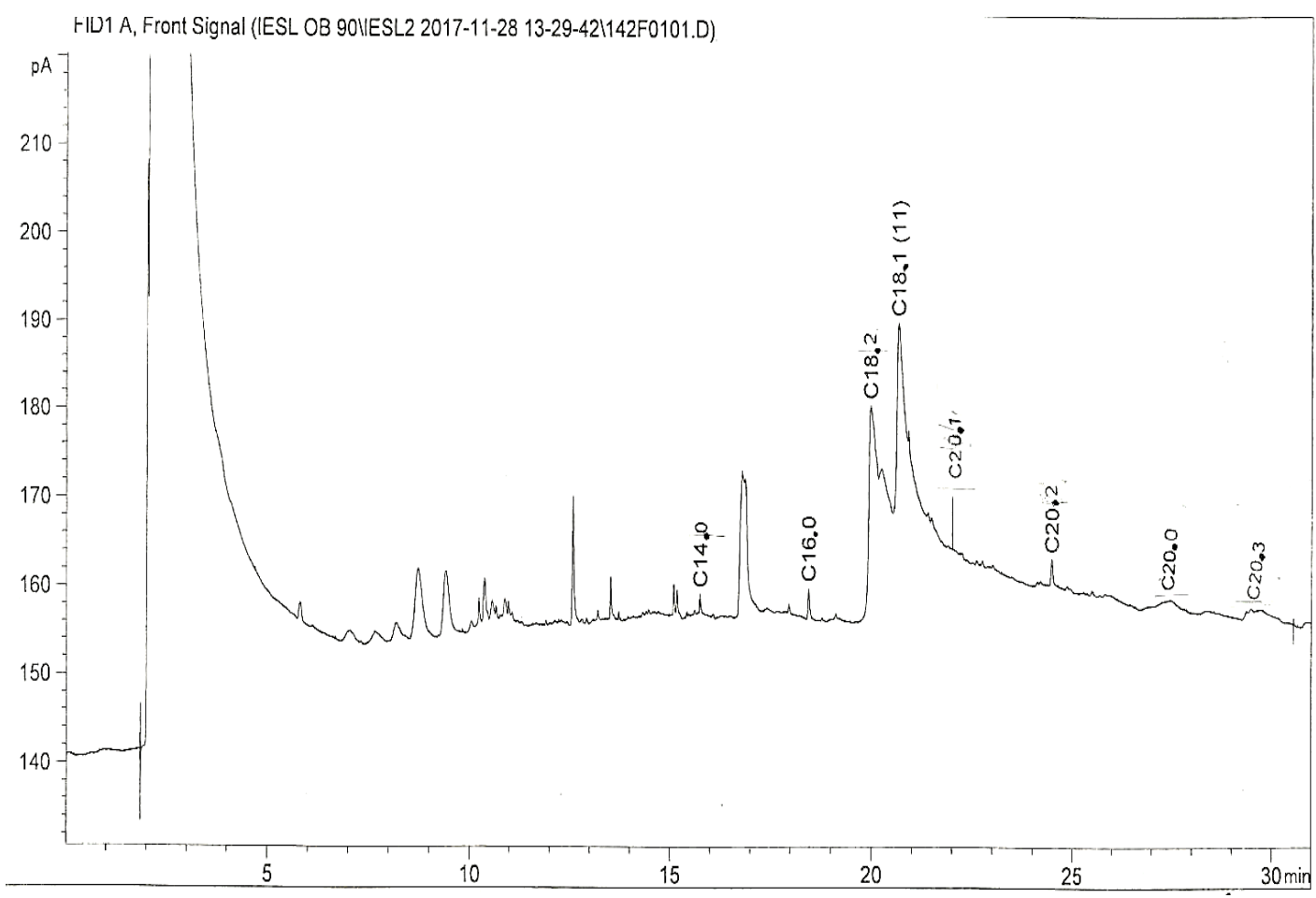

Figure 4. Fatty acid GC chromatogram of African pear pulp oil (APPO).

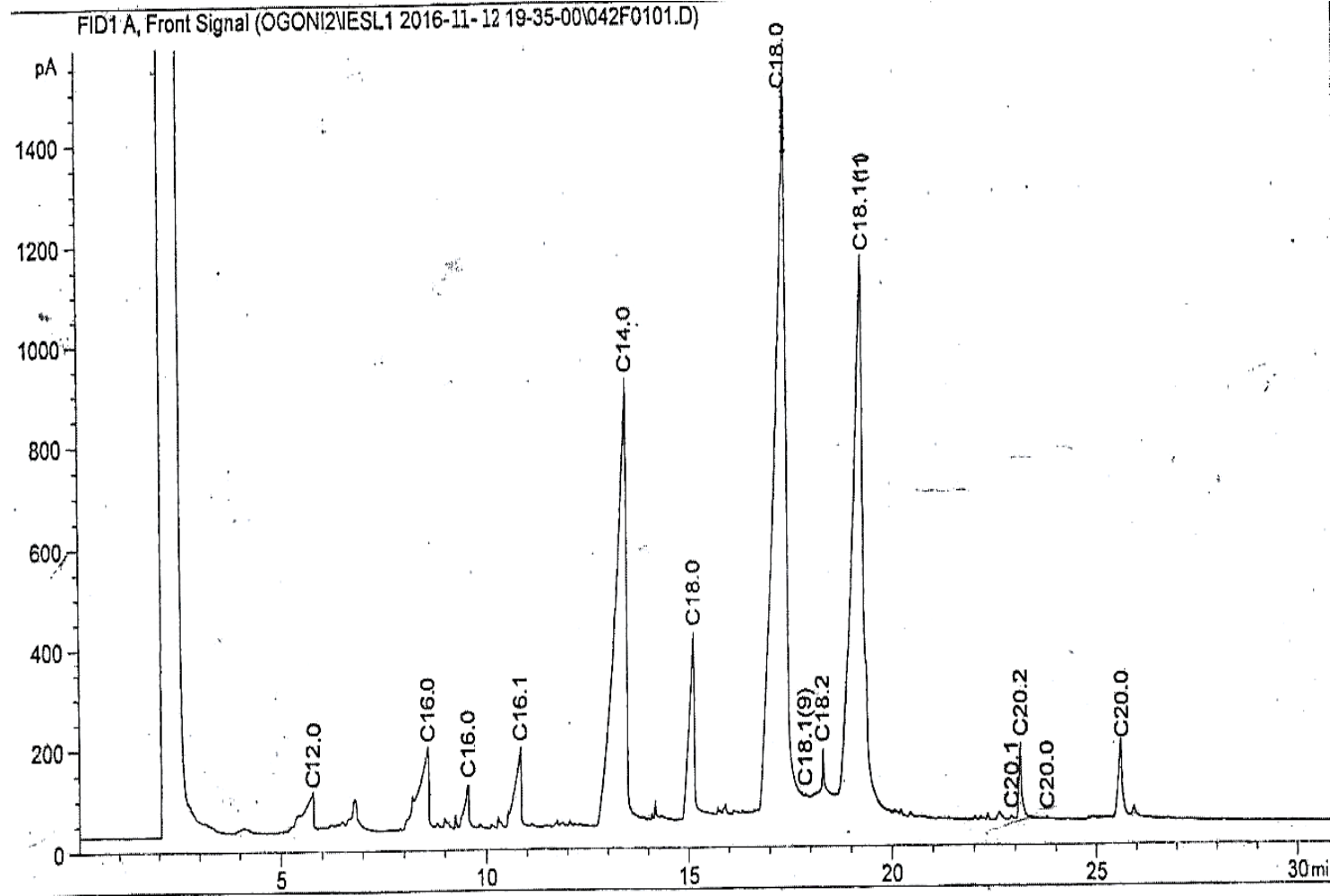

Figure 5. Fatty acid GC Chromatogram of Allanblackia seed oil (ASO).

melting point of 25.34 and $35.40^{\circ} \mathrm{C}$, respectively. The slip melting point defines the temperature at which fat becomes sufficiently fluid to run or slip, or the temperature at which it softens. The high melting point of 


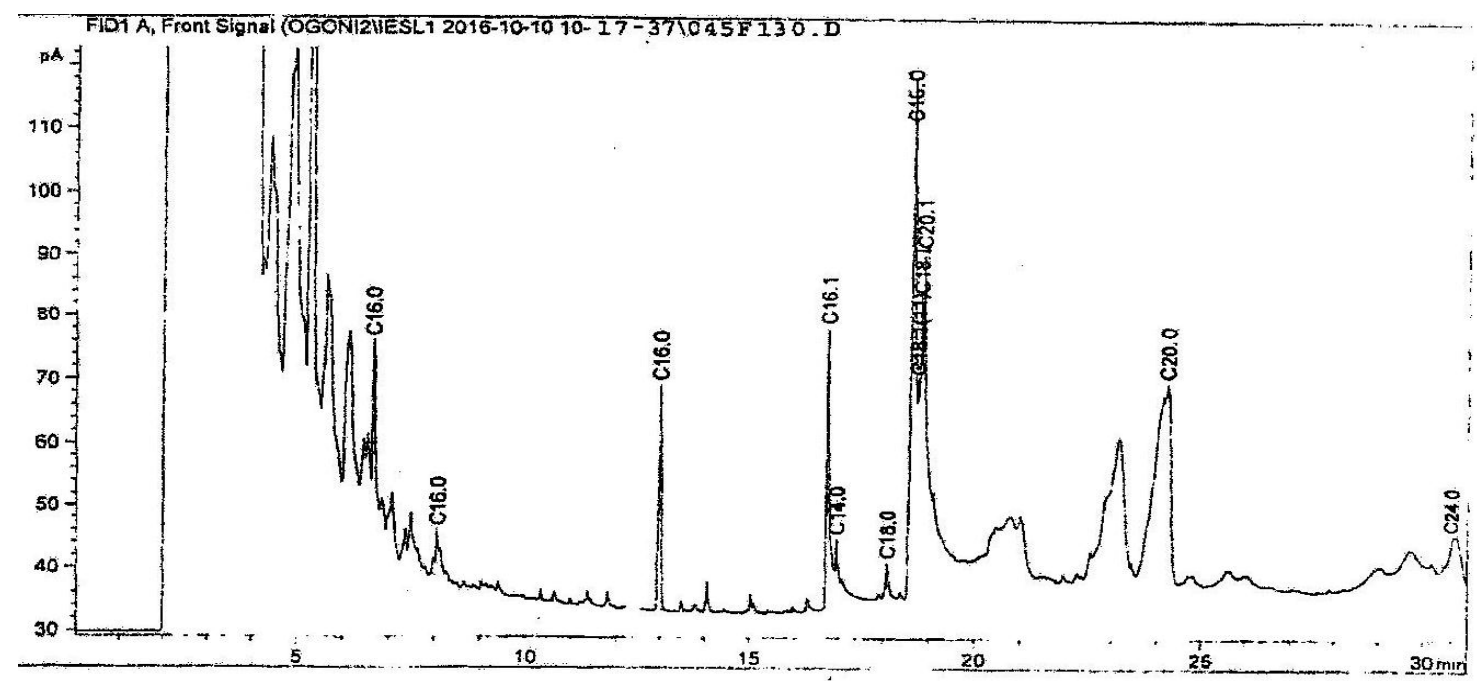

Figure 6. Fatty acid GC chromatogram of crude palm oil (CPO).

Table 3. Physical properties of African pear pulp oil, Allanblackia seed oil and palm oil.

\begin{tabular}{lcccccc}
\hline Sample & VS (cst) & Dn & R1 & SMP $\left({ }^{\circ} \mathbf{C}\right)$ & SMOK.P. $\left({ }^{\circ} \mathbf{C}\right)$ & Colour intensity \\
\hline APPO & $42.24 \pm 0.488^{\mathrm{a}}$ & $0.893 \pm 0.002^{\mathrm{b}}$ & $1.4675 \pm 0.000^{\mathrm{a}}$ & $25.34 \pm 0.608^{\mathrm{c}}$ & $190.39 \pm 0.396^{\mathrm{c}}$ & $\begin{array}{c}6.0 \mathrm{R} \\
20 \mathrm{y}\end{array}$ \\
& & & & & \\
& & & & & \\
ASO & $21.76 \pm 0.156^{\mathrm{b}}$ & $0.889 \pm 0.00^{\mathrm{b}}$ & $1.4650 \pm 0.000^{\mathrm{a}}$ & $35.40 \pm 0.587^{\mathrm{a}}$ & $219.83 \pm 0.319^{\mathrm{b}}$ & $\begin{array}{c}20 \mathrm{y} \\
\end{array}$ \\
& & & & & $11 \mathrm{R}$ \\
CPO & $42.46 \pm 0.014^{\mathrm{a}}$ & $0.900 \pm 0.001^{\mathrm{a}}$ & $1.456 \pm 0.001^{\mathrm{b}}$ & $32.57 \pm 0.0014^{\mathrm{b}}$ & $230.05 \pm 0.58^{\mathrm{a}}$ & $22 \mathrm{y}$ \\
\hline
\end{tabular}

Values are means \pm standard deviation of duplicate samples.

Mean values bearing different superscripts in the same column differ significantly $(p<0.05)$.

Key: RI = Refractive index, Dn = Density, SMP = Slip melting point, SMOKE P. = smoke point, VS = Viscosity, L.C $=$ Lovibond colour, APP $=$ African Pear Pulp, ASO = Allanblackia Seed Oil, CPO = Crude palm oil.

Allanblackia seed oil keeps it solid at room temperature, this property will help provide a good solid support for margarine and shortenings.

African pear pulp oil and Allanblackia seed oil gave high smoke point of 190.39 and $219.83^{\circ} \mathrm{C}$, respectively. High value of smoke point is an indication that these oils can be used for a wide range of cooking application. The temperature at which oil gives off a steel bluish smoke when heated is termed smoke point. Fat decompose or breaks down into glycerol and its individual fatty acids when overheated. The glycerol further undergo hydrolyses to produce a thin-blue acrolein smoke (Bockish, 1998). As reported by Thomas (2002), the smoke point serves as an indicator to the temperature limit which a particular cooking oil can be used. It has a negative correlation with the percentage free fatty acid of the oil (Thomas, 2002). Increase in smoke point occurs when the free fatty acid content decreases and when the degree and efficiency of refinement increases (Bockish, 1998).
Result for Lovibond colour intensity, showed Allanblackia seed oil having $2.5 \mathrm{red}$, and African pear pulp oil 6.0 red. These values were much lower than the crude palm oil (11 red), implying that less energy and materials will be needed to bleach African pear pulp oil than would be needed to bleach palm oil. The intensity of red pigments $(R)$ in all the oil samples were lower than, and within the standard range of $5 \mathrm{R}$ to $20 \mathrm{R}$ ( $\max$ ) for crude vegetable oil (IS 8323, 2014; MS 814, 2007). The standard colour range for refined vegetable oil is 1 to 3 red (NIS 289, 1992). As such, the extracted African pear pulp oil needs refining and bleaching before use, while Allanblackia seed oil need no refining.

\section{Solid fat content of Allanblackia seed oil, African pear pulp oil and crude palm oil}

As shown in Figure 7, Allanblackia seed oil gave a steep curve with solid fat content of $98.70 \%$ at $5^{\circ} \mathrm{C}$, and $0 \%$ at 


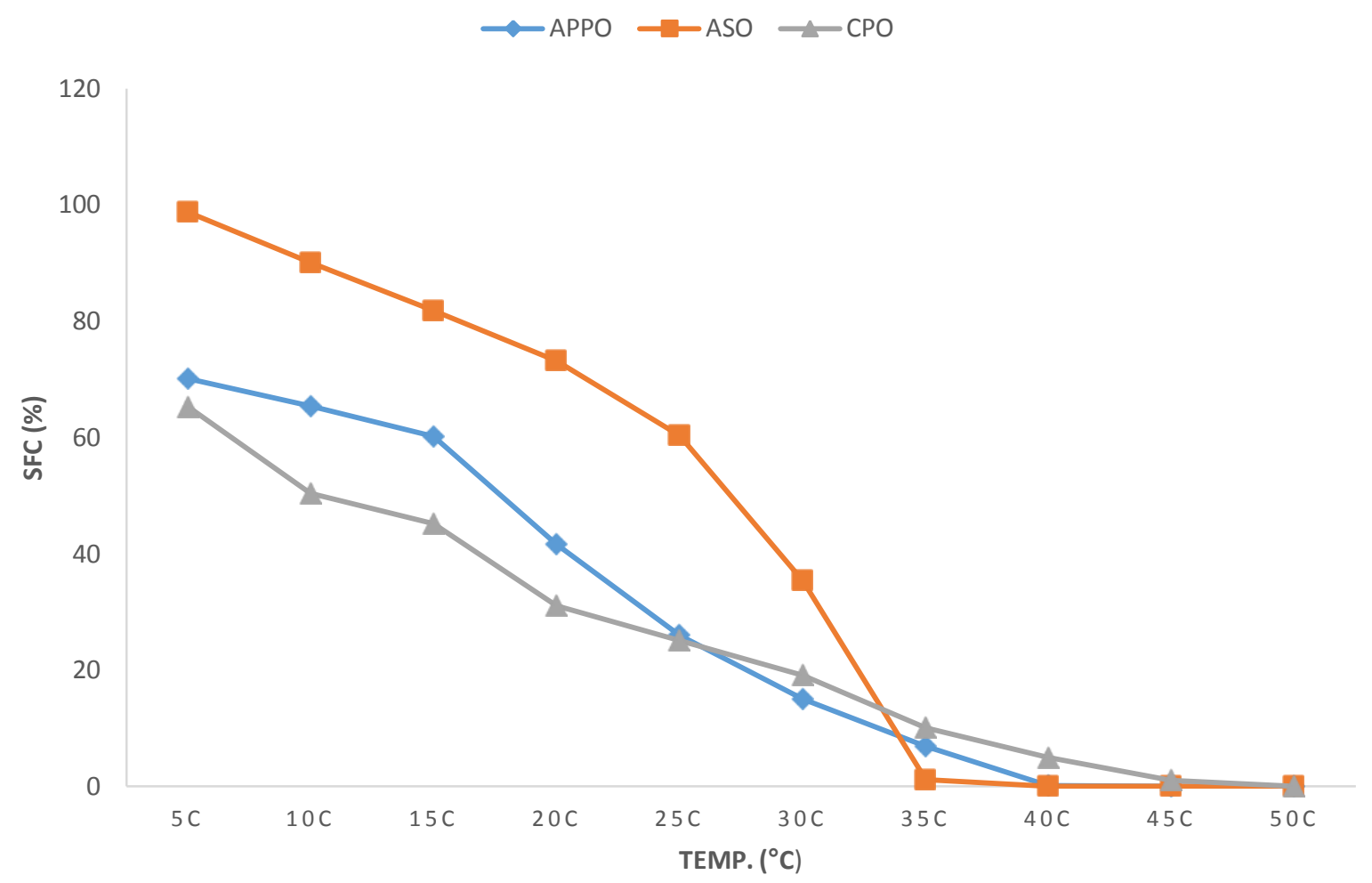

Figure 7. Solid fat content - Temperature profile of African pear pulp oil, Allanblackia seed oil and crude palm oil. Key: APPO = African pear pulp oil; ASO = Allanblackia seed oil; CPO = crude palm oil.

$40^{\circ} \mathrm{C}$. African pear pulp oil showed percentage solid fat of $70 \%$ at $5^{\circ} \mathrm{C}$ and $0.1 \%$ at $40^{\circ} \mathrm{C}$, with a flat curve and relatively wider plastic range, showing that Allanblackia seed oil will help to provide the needed solid content while African pear pulp oil will provide the needed plasticity and spreadability of margarine and shortenings if manufactured from there blend.

\section{CONCLUSION AND RECOMMENDATION}

African pear pulp and Allanblackia seed gave 48.93 and $65.31 \%$ yield of oil, indicating that they are good sources of vegetable oil. High smoke point of African pear pulp oil and Allanblackia seed oil (190.39 and $219.83^{\circ} \mathrm{C}$ ) indicate that they can be used for high temperature cooking including frying and baking. African pear pulp oil contained $65.88 \%$ of unsaturated fatty acids with $23.17 \%$ linoleic acid (Omega-6), $0.84 \%$ eicosadienoic acid (omega-6) and $0.51 \%$ eicosatrienoic acid (Omega-3). These are polyunsaturated and essential fatty acids, safe, heart friendly and nutritionally desirable. Allanblackia seed oil had more stearic acid and less palmitic acid, making it a healthy source of solid base fat for shortening and margarine production. However, effect of fat modifications (blending) on the physicochemical properties and fatty acid composition of shortenings formulated with Allanblackia seed and African pear pulp oils shall be investigated in the next study.

\section{REFERENCES}

Ajayi IA and Adesanwo O (2009). Comparative Study of the Mineral Element and Fatty Acid Composition of Dacryodes edulis Pulp and Seed. Word J. Agric. Sci. 5(3):279-283.

AOAC (2012). Official Methods of Analysis of the Association of Analytical Chemists. 19th Edition. Washington, DC, USA.

Aremu MO, Ibrahim H, Bamidele TO (2015). Physicochemical Characteristics of the Oils Extracted from Some Nigerian Plant Foods. Chem. Process Eng. Res. 32:22-25.

Atangana AR, van der Vlis E, Khasa DP, van Houten D, Beaulieu J, Hendrickx H (2011). Tree-to-tree variation in stearic and oleic acid content in seed fat from Allanblackia floribunda from wild stands: Potential for tree breeding. Food Chem. 126(4):1579-1585

Bockish M (1998). Fats and Oils Handbook, Champaign, IL: American Oil Chemists' Society Press.

Chibor BS, Kiin-Kabari DB, Ejiofor J (2017). Physicochemical Properties and Fatty Acid Profile of Shea Butter and Fluted Pumpkin Seed Oil, a Suitable Blend in Bakery Fat Production. Int. J. Nutr. Food Sci. 6(3):122-128.

CODEX-STAN (1999). CODEX Alimentairus Commission Standard for Named Vegetable Oils, FAO Corporate Document, CODEX STAN 210. Retrieved from https://www.fao.org/docrep/004/y2774e05. $5^{\text {th }}$ July, 2017.

CODEX STAN (2011). CODEX Alimentairus Commission Standard for Fats and Oil Derived from Edible Fats and Oils, FAO Corporate Document, CODEX STAN 32. Retrieved from https://www.fao.org/docrep/004/y2774e06. $5^{\text {th }}$ July, 2017

Folarin MO, Oreniyi SA, Oladipo GO (2017). Physicochemical and Kinetics Parameters of Allanblackia floribunda Seed Oil and some of its Metal Carboxylates. Sci. Int. 5(2):56-62.

Hoffman G (1986). Quality Control in Food Industry. Food Science and Technology Series of Monographs, $2^{\text {nd }}$ ed. (pp. 407-504). London: Academic press. Retrieved from https://www.elsevier.com. $6^{\text {th }}$ June, 2016.

Ikhuoria EU, Maliki M (2007). Characterization of avocado pear (Persea 
americana) and African pear (Dacryodes edulis) extracts. Afr. J. Biotechnol. 6(7):950-952.

Indian Standard (IS 8323) (2014). Indian Standard for Palm Oil Specifications. FAD Doc. No: 13(2634). Retrieved from http://www.bis.org.in. 16 $6^{\text {th }}$ August, 2017.

Kapseu C, Mapongmetsem PM, Silou T, Roques M (1999). Physicochemistry of Cameroonian Safou tree fruits Dacryodes edulis. Tropicultura. 16-17(1):98-99.

Masters ET, Yidane JA, Loveth PN (2004). Reinforcing Sound Management through Trade: Shea Tree Products in Africa. J. For. Fores. Res. 210:46-52.

McClements DJ (1999). Food Emulsions: Principles, Practice and Techniques. Boca Raton, Florida: CRC Press.

Malaysian Standard (MS 814). (2007). Malaysian Standard for Palm Oil. Malaysia Palm Oil Board, Official Palm Oil Info. Retrieved from http://www.palmoilworld.org. $16^{\text {th }}$ August, 2017.

Nahm HS (2011). Quality Characteristics of West African Shea butter (Vitellaria Paradox) and Approaches to Extend Shelf-Life. Retrieved from https://rucore.libraries.rutgers.edu. $11^{\text {th }}$ May, 2017.

Nazaruddin R (2013). Determination of SFC in Oils and Fats. Advance Chemical Analysis of Food Laboratory. Retrieved from https://sitiradhiahabrazak.files.wordpress.com. $2^{\text {nd }}$ June, 2017.

Nielson SS (1994). Introduction to Chemical Analysis of Foods. New York: Chapman and Hall.

Noumi GB, Djounja T, Ngameni E, Kapseu C (2014). Influence of the storage time on the fats and oil composition of Safou (Dacryodes edulis) dried pulp. Int. Food Res. J. 21(5):1837-1841.

Novella Partnership (2008). www.snvworld.org or http://www.allanblackia.info.

Ogoloma UJ, Nkpaa KW, Akininwo JO, Uwakwe AA (2013) Proximate, Phytochemical and Mineral Elements Composition of some Edible Fruits Grown in Oil Producing Communities of Rivers State, Nigeria, J. Environ. Sci. Toxicol. Food Technol. 5(2):38-46.

Orheuba BA, Jinadu AO (2011). Determination of Physico-Chemical Properties and Nutritional Contents of Avocado Pear (Persea Americana M.). Acad. Res. Int. 1(3):372-380.

Okashi VE, Oguga VN, Ugian EA, Njoku OU (2013). Physico-Chemical Properties of Fluted Pumpkin (Telfaria occidenttalis Hook F) Seeds. Int. J. Eng. Sci. 2(9):36-38.
Ononogbu IC (2002). Lipid in Human Existence. Ap Express, Nsukka pp. 1-80.

Gordon MD (1993). Fats, fatty foods, In Ranken, M. D, and Kill, R. C (eds). Food Industries Manual $23^{\text {rd }}$ edn. Blacke Academic and Professional, London, pp. 179-186.

Rios RV, Pessanha MDF, Almeida PF, Viana CL, Lanne SC (2014). Application of fat in some food products. Food Sci. Technol. (Campinas), 3(1):315.

Silou T (2012). Oils and Fats for the Future. A Case Study: Safou (Dacryodes edulis) from the Congo Basin Countries in Africa. Hauppauge, NY, USA: Nova Science Publishers.

Thomas A (2002). Fats and Fatty Oils. Ullman's Encyclopaedia of Industrial Chemistry. Retrieved from https://www.coursehero.com. $15^{\text {th }}$ June, 2017.

Wilfred S, Adubofuor J, Oldham JH (2010). Optimum conditions for expression of oil from Allanblackia floribunda seeds and assessing the quality and stability of pressed and solvent extracted oil. Afr. J. Food Sci. 4(9):563-570.

AOAC (2012). Association of Official Analytical Chemist, official methods of Analysis, $19^{\text {th }}$ edition, Washington, D. C.

Shahidi F (2005). Quality Assurance of Fats and oils. In: Bailey's Industrial oil and fats products, Shahidi, F. (Ed). 6A Edn. John Wily and Sons Inc., USA.

Nielson SS (1994). Introduction to the chemical Analysis of Foods. Chapman and Hall, New York, USA, pp. 93-207.

Nourrechni H, Teoh BC, Clement LD (1992). Viscosity of vegetable oils and fatty acids. J. Am. Chem. Soc. 69:1184-1188.

http://www.sciencewebpublishing.net/ijbfs 